\title{
Properties of Concrete using Eggshell Powder and Glass Powder as a Cement Replacement
}

\author{
A. Arunya, S. Thendral, R. Chitra
}

\begin{abstract}
The point of this undertaking is to forestall the contamination in the earth caused because of ill-advised transfer of the eggshell waste and glass powder by utilizing it as an added substance material in type of cinder or powder in ordinary cement of M25 level since it is utilized typically in the building destinations.This venture focuses on blend structure, material testing of element of cement, for example, concrete, fine total, coarse total and eggshell powder (ESP)and glass powder (GP). Solid 3D shapes with different preliminary rates of eggshell powder and glass powder were thrown. The glass powder and eggshell powder contains silica and calcium separately which thus contributes in calcium - silicate gel development offering raise to the great security quality between the totals and concrete glue. In this examination, the glass powder and egg shell powder were utilized at $0 \%, 5 \%, 10 \%$, and $15 \%$ individually. The test outcomes acquired shows compelling quality increment at $10 \%$ substitution of ESP and GP.
\end{abstract}

Key words: Ca - Si Gel, Egg shell powder, Glass powder, Compressive strength, Water absorption study..

\section{INTRODUCTION}

Pressure driven Concrete is viewed as more grounded and more strong than before and being cost and vitality effective. It is otherwise called the spine to the framework improvement of a nation[1],[3],[5]. At present, the development business isn't practical chiefly because of the utilization of normal materials , the gigantic sum in outflow of green house gas from the assembling place .Nowadays solid structures are experiencing the issue of solidness because of the wastage of regular assets are squandered . In this way, there is a need to discover an elective strategy so solid industry winds up economical[2 ],[4],[6].The concrete creates about $5 \%$ of $\mathrm{CO} 2$ discharges of the world. Subsequently, at present , the whole development industry is in a hunt of a reasonable and powerful the waste item that would impressively limit the utilization of bonds and at last lessens the development cost .And additionally the side-effects, for example, egg shells, glass powders and fly fiery remains are making natural and medical issues. Accordingly, in this present examination the eggshell

Revised Manuscript Received on July 22, 2019

A.Arunya, Assistant Professor, Department of Civil Engineering, Bharath Institute Of Education And Research, Chennai, Tamil Nadu.

E- Mail : arunyaaaa@gmail.com

S. Thendral, Assistant Professor, Department of Civil Engineering, Bharath Institute Of Education And Research, Chennai , Tamil Nadu.

E- Mail : thendral.cs@gmail.com

R. Chitra, Assistant Professor, Department of Civil Engineering, Bharath Institute Of Education And Research, Chennai, Tamil Nadu.

E- Mail : chitraroopauma@gmail.com powder and glass powder are utilized in concrete as an incomplete substitution of bond [20],[22], [24]

A portland bond is made out of significant oxides : lime $(\mathrm{Ca} \mathrm{O})$, Silica (SiO2), Alumina(Al2O3). The lime gives the solidarity to concrete, Eggshell are wealthy in the lime so it utilized as the substitution of folio in the solid. In development, cement is a composite structure material produced using the mix of total and a concrete folio. The most widely recognized type of solid comprise of Portland bond , mineral total ( by and large rock and sand) and water.

\section{METHODOLOGY}

\section{A. Materials}

Following materials are utilized for the accompanying task.

B. Cement

Customary Portland bond of 53 evaluation is to be utilized for the examination.

\section{Fine Aggregate}

Locally accessible stream sand fine totals are utilized in the examination.

\section{Coarse Aggregate}

Locally accessible coarse total are taken and sieved to the required amount of volume to the most extreme ostensible size $12 \mathrm{~mm}$. Care is taken to arrive the size of coarse total running from $4.75 \mathrm{~mm}$ to the most extreme ostensible size of $12 \mathrm{~mm}$. [31],[33]

\section{E.Powder and Glass Powder}

Eggshell Powder and Glass Powder .

\section{F. Water}

Normal convenient water utilized in this undertaking. [32],[34]

\section{G . Casting of cubes}

Throwing of solid shapes Solid 3D shape examples of measurement $150 \mathrm{~mm} \times 150 \mathrm{~mm} \times 150 \mathrm{~mm}$ were thrown for the examination

\section{H. Curing of Specimens}

After de-molding the specimens place it for curing for water absorption test. 
Properties of Concrete Using Eggshell Powder and Glass Powder as A Cement Replacement

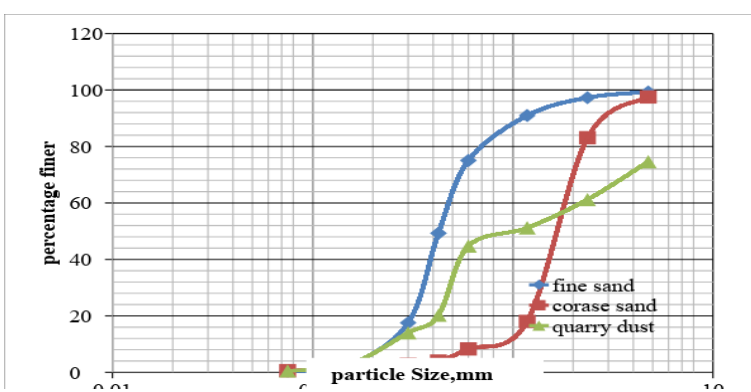

Fig. 1 Particle size distribution of soil samples

\section{EXPERIMENTAL INVESTIGATION}

\section{A. Compressive Strength}

The pressure testing is an exceptionally basic testing technique that is utilized to set up the compressive power or pulverize obstruction of a material and the capacity of the material to recoup after a predetermined compressive power is connected and even held over a characterized timeframe. Pressure tests are utilized to decide the material conduct under a heap. The most extreme pressure a material can support over a period under a heap (consistent or dynamic) is determined[25],[27],[29]

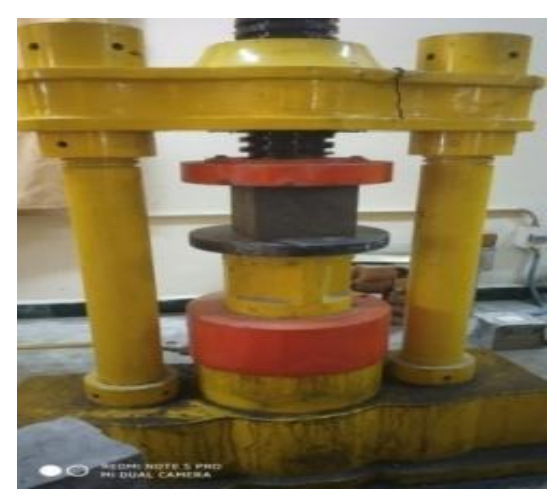

Fig 2: Compression Test of cube specimen

\section{RESULT AND DISCUSSION}

Table 1: 7 days and 28 days results of Compressive Strength

\begin{tabular}{|c|c|c|c|}
\hline PERCENTAGE & $\begin{array}{l}\text { COMPRESSION } \\
\text { TEST RESULT } \\
\text { FOR 7 DAYS } \\
\left(\mathrm{N} / \mathrm{mm}^{2}\right)\end{array}$ & $\begin{array}{l}\text { COMPRESSION } \\
\text { TEST RESULT } \\
\text { FOR 28 DAYS } \\
\left(\mathrm{N} / \mathrm{mm}^{2}\right)\end{array}$ & $\begin{array}{c}\text { WEIGHT } \\
\text { (KG) }\end{array}$ \\
\hline $0 \%$ & 13.90 & 28 & 8.810 \\
\hline $5 \%$ & 14.31 & 28.42 & 8.452 \\
\hline $10 \%$ & 15.23 & 29.43 & 8.460 \\
\hline $15 \%$ & 14.21 & 25.34 & 8.432 \\
\hline
\end{tabular}

Table 1- Compression Test at 7 days

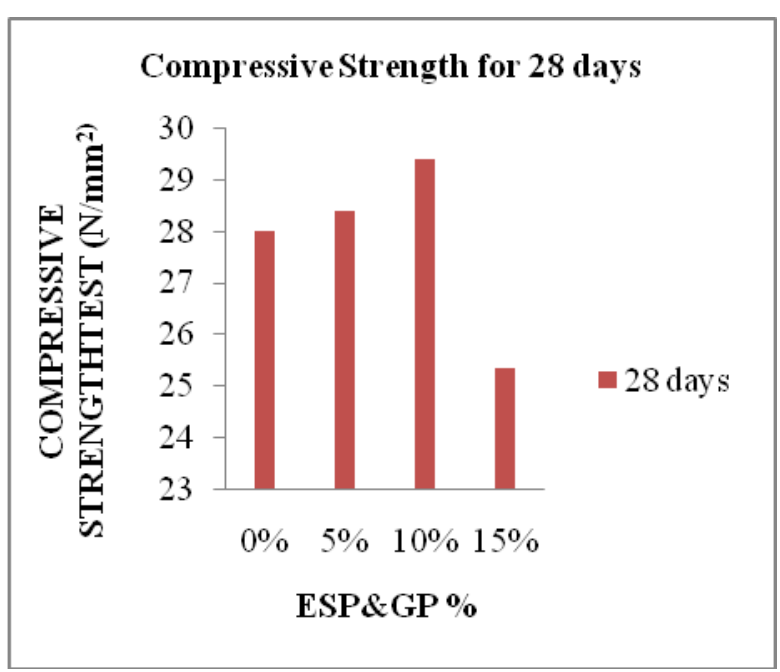

Fig 3: Compression Test at 28 days

\section{A. Water Absorption}

In water ingestion test the examples are dried in a broiler for 72 hours at 110 degree celsius and after that put in a desiccators to cool[26],[28],[30] . Promptly after cooling the examples are gauged and this considered as (W1). The material is then inundated in water for 24 hours. Examples are evacuated, at that point dry with build up free material and gauged and this considered as (W2)

\section{CONCLUSION}

1. The ESP and GP goes about as an amazing elective material for bond

2. The calcium (Ca) in ESP and silica gel ( $\mathrm{Si}$ ) in GP expands the pozzolonic action and Thereby gives great restricting quality in the solid examples.

3. Based on the test outcome $10 \%$ of ESP and $10 \%$ GP was established to be ideal

Published By: 
4. At the finish of 7 days outcome there was around $9 \%$ expansion quality in correlation with control example@10\% substitution of ESP and GP separately

5. With increase in percentage (\%) of ESP + GP there was an effective decrease in water absorption study carried out @28 days

\section{REFERENCES}

1. Iyappan L., Dayakar P., Identification of landslide prone zone for coonoortalukusing spatial technology, International Journal of Applied Engineering Research,V-9,I-22,PP-5724-5732,Y-2014.

2. Kumar J., Sathish Kumar K., Dayakar P.,Effect of microsilica on high strength concrete, International Journal of Applied Engineering Research,V-9,I-22,PP-5427-5432,Y-2014.

3. Dayakar P., Vijay Ruthrapathi G., Prakesh J., Management of bio-medical waste, International Journal of Applied Engineering Research,V-9,I-22,PP-5518-5526,Y-2014.

4. Swaminathan N., Dayakar P., Resource optimization in construction project, International Journal of Applied Engineering Research,V-9,I-22,PP-5546-5551,Y-2014.

5. Venkat Raman K., Dayakar P., Raju K.V.B.,An experimental study on effect of cone diameters in penetration test on sandy soil, International Journal of Civil Engineering and Technology,V-8,I-8,PP-1581-1588,Y-2017.

6. Saritha B., Chockalingam M.P.,Photodradation of malachite green DYE using TIO2/activated carbon composite,International Journal of Civil Engineering and Technology,V-8,I-8,PP-156-163,Y-2017

7. Shendge R.B., Chockalingam M.P., Saritha B., Ambica A.,Swat modelling for sediment yield: A case study of Ujjani reservoir in Maharashtra, India,International Journal of Civil Engineering and Technology,V-9,I-1,PP-245-252,Y-2018

8. Chockalingam M.P., Balamurgan V.,Modernisation of an existing urban road-sector in Chennai, a case study report,International Journal of Civil Engineering and Technology,V-8,I-8,PP-1457-1467,Y-2017

9. Saritha B., Chockalingam M.P.,Adsorption study on removal of basic dye by modified coconut shell adsorbent, International Journal of Civil Engineering and Technology,V-8,I-8,PP-1370-1374,Y-2017

10. Saritha B., Chockalingam M.P.,Adsorptive removal of heavy metal chromium from aqueous medium using modified natural adsorbent,International Journal of Civil Engineering and Technology,V-8,I-8,PP-1382-1387,Y-2017

11. Chockalingam M.P., Palanivelraja S.,Retrospective analysis of a theoretical model used for forecasting future air quality near the north Chennai thermal power plant,International Journal of Civil Engineering and Technology,V-8,I-8,PP-1457-1467,Y-2017

12. Saritha B., Chockalingam M.P.,Photodegradation of methylene blue dye in aqueous medium by $\mathrm{Fe}-\mathrm{AC} / \mathrm{TiO} 2$ Composite,Nature Environment and Pollution Technology,V-17,I-4,PP-1259-1265,Y-2018

13. Shendge R.B., Chockalingam M.P., Kaviya B., Ambica A.,Estimates of potential evapotranspiration rates by three methods in upper Bhima Basin, In Maharashtra, India,International Journal of Civil Engineering and Technology,V-9,I-2,PP-475-480,Y-2018

14. Shendge R.B., Chockalingam M.P.,The soil and water assessment tool for Ujjani Reservoir,International Journal of Mechanical Engineering and Technology,V-9,I-2,PP-354-359,Y-2018

15. Shendge R.B., Chockalingam M.P.,A review on soil and water assessment tool,International Journal of Mechanical Engineering and Technology,V-9,I-2,PP-347-353,Y-2018

16. Sachithanandam P., Meikandaan T.P., Srividya T.,Steel framed multi storey residential building analysis and design,International Journal of Applied Engineering Research,V-9,I-22,PP-5527-5529,Y-2014

17. Meikandaan T.P., Ramachandra Murthy A.,Study of damaged RC beams repaired by bonding of CFRP laminates,International Journal of Civil Engineering and Technology,V-8,I-2,PP-470-486,Y-2017

18. Meikandaan T.P., Ramachandra Murthy A.,Retrofittng of reinforced concrete beams using GFRP overlays,International Journal of Civil Engineering and Technology,V-8,I-2,PP-423-439,Y-2017

19. Meikandaan T.P., Ramachandra Murthy A.,Flexural behaviour of RC beam wrapped with GFRP sheets,International Journal of Civil Engineering and Technology,V-8,I-2,PP-452-469,Y-2017

20. Meikandaan T.P., Murthy A.R.,Experimental study on strengthening of rc beams using glass Fiber,International Journal of Civil Engineering and Technology,V-9,I-11,PP-959-965,Y-2018

21. Meikandaan T.P., Hemapriya M.,Use of glass FRP sheets as external flexural reinforcement in RCC Beam,International Journal of Civil Engineering and Technology,V-8,I-8,PP-1485-1501,Y-2017
22. Saraswathy R., Saritha B.,Planning of integrated satellite township at Thirumazhisai,International Journal of Applied Engineering Research,V-9,I-22,PP-5558-5560,Y-2014

23. Saritha B., Ilayaraja K., Eqyaabal Z.,Geo textiles and geo synthetics for soil reinforcement,International Journal of Applied Engineering Research,V-9,I-22,PP-5533-5536,Y-2014

24. Ambica A., Saritha B., Changring G., Singh N B., Rajen M., Salman Md.,Analysis of groundwater quality in and around Tambaram taluk, Kancheepuram district,International Journal of Civil Engineering and Technology,V-8,I-8,PP-1362-1369,Y-2017

25. Arunya A., Sarayu K., Ramachandra Murthy A., Iyer N.R.,Enhancement of durability properties of bioconcrete incorporated with nano silica,International Journal of Civil Engineering and Technology,V-8,I-8,PP-1388-1394,Y-2017

26. Ilayaraja K., Krishnamurthy R.R., Jayaprakash M., Velmurugan P.M., Muthuraj S.,Characterization of the 26 December 2004 tsunami deposits in Andaman Islands (Bay of Bengal, India),Environmental Earth Sciences, V-66,I-8,PP-2459-2476,Y-2012

27. Ilayaraja K.,Morphometric parameters of micro watershed in Paravanar sub-basin, Cuddalore District,International Journal of Civil Engineering and Technology,V-8,I-8,PP-1444-1449,Y-2017

28. Ilayaraja K., Singh R.K., Rana N., Chauhan R., Sutradhar N.,Site suitability assessment for residential areas in south Chennai region using remote sensing and GIS techniques,International Journal of Civil Engineering and Technology,V-8,I-8,PP-1468-1475,Y-2017

29. Ilayaraja K., Reza W., Kumar V., Paul S., Chowdhary R.,Estimation of land surface temperature of Chennai metropolitan area using Landsat images,International Journal of Civil Engineering and Technology,V-8,I-8,PP-1450-1456,Y-2017

30. Chitra R.,Experimental study on beam using steel fiber and latex,International Journal of Civil Engineering and Technology,V-8,I-8,PP-1395-1403,Y-2017

31. Chitra R.,Analysis of traffic and management at Kovilambakkam intersection,International Journal of Civil Engineering and Technology,V-8,I-8,PP-1433-1443,Y-2017

32. Aswathy M.,Experimental study on light weight foamed concrete,International Journal of Civil Engineering and Technology,V-8,I-8,PP-1404-1412,Y-2017

33. Aswathy M.,Wastewater treatment using constructed wetland with water lettuce (Eichornia Crasipies),International Journal of Civil Engineering and Technology,V-8,I-8,PP-1413-1421,Y-2017

34. Kiruthiga K., Anandh K.S., Gunasekaran K, Assessment of influencing factors on improving effectiveness and productivity of construction engineers, 2015, International Journal of Applied Engineering Research, V - 10,I -17,p -13849-13854.

\section{AUTHORS PROFILE}

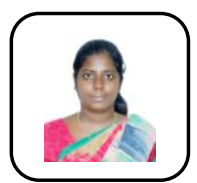

A.Arunya Assistant Professor, Department of Civil Engineering, Bharath Institute of Higher Education and Research, Chennai, India

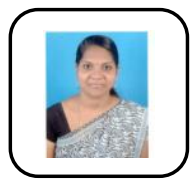

S. Thendral, Assistant Professor, Department of Civil Engineering, Bharath Institute of Higher Education and Research, Chennai, India

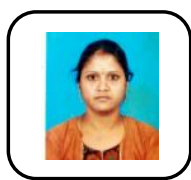

R. Chitra, Assistant Professor, Department of Civil Engineering, Bharath Institute of Higher Education and Research, Chennai, India 